\title{
Discovery of Pyrazolo[1,5-a]pyrimidine TTK Inhibitors: CFI-402257 is a Potent, Selective, Bioavailable Anticancer Agent
}

\author{
Yong Liu, ${ }^{\dagger}$ Radoslaw Laufer, ${ }^{\dagger}$ Narendra Kumar Patel, ${ }^{\dagger}$ Grace $\mathrm{Ng}^{\dagger}{ }^{\dagger}$ Peter B. Sampson, ${ }^{\dagger}$ Sze-Wan $\mathrm{Li}^{\dagger}{ }^{\dagger}$
} Yunhui Lang, ${ }^{\dagger}$ Miklos Feher, ${ }^{\dagger}$ Richard Brokx, ${ }^{\dagger}$ Irina Beletskaya, ${ }^{\dagger}$ Richard Hodgson, ${ }^{\dagger}$ Olga Plotnikova, ${ }^{\dagger}$ Donald E. Awrey, ${ }^{\dagger}$ Wei Qiu, ${ }^{\ddagger}$ Nickolay Y. Chirgadze, Jacqueline M. Mason, ${ }^{\dagger}$ Xin Wei, ${ }^{\dagger}$ Dan Chi-Chia Lin, ${ }^{\dagger}$ Yi Che, ${ }^{\dagger}$ Reza Kiarash, ${ }^{\dagger}$ Graham C. Fletcher, ${ }^{\dagger}$ Tak W. Mak, ${ }^{\dagger}$ Mark R. Bray, ${ }^{\dagger}$ and Henry W. Pauls ${ }^{*}{ }^{\dagger}$

${ }^{\dagger}$ Campbell Family Institute for Breast Cancer Research, University Health Network, TMDT East Tower, MaRS Centre, 101 College Street, Toronto, Ontario M5G 1L7, Canada

${ }^{\ddagger}$ Campbell Family Cancer Research Institute, University Health Network, Princess Margaret Cancer Center, 610 University Avenue, Toronto, Ontario M5G 2C4, Canada

\section{Supporting Information}

ABSTRACT: This work describes a scaffold hopping exercise that begins with known imidazo[1,2-a]pyrazines, briefly explores pyrazolo $[1,5-a][1,3,5]$ triazines, and ultimately yields pyrazolo $[1,5-a]$ pyrimidines as a novel class of potent TTK inhibitors. An X-ray structure of a representative compound is consistent with $1 \frac{1}{2}$ type inhibition and provides structural insight to aid subsequent optimization of in vitro activity and physicochemical and pharmacokinetic properties. Incorpora-

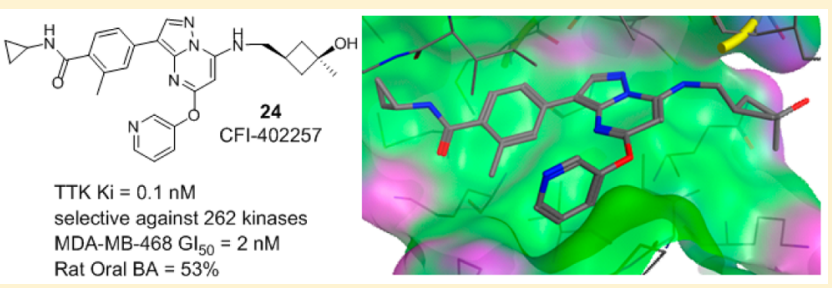
tion of polar moieties in the hydrophobic and solvent accessible regions modulates physicochemical properties while maintaining potency. Compounds with enhanced oral exposure were identified for xenograft studies. The work culminates in the identification of a potent (TTK $K_{\mathrm{i}}=0.1 \mathrm{nM}$ ), highly selective, orally bioavailable anticancer agent (CFI-402257) for IND enabling studies.

KEYWORDS: TTK inhibitors, CFI-402257, pyrazolo[1,5-a]pyrimidines, $1^{1} / 2$ type inhibitors

$\mathrm{T}$ hreonine tyrosine kinase (TTK) has been a drug discovery focus $^{1,2}$ in our laboratory since it was identified by an internal RNAi screen. ${ }^{3}$ The growth of 7 of 12 breast cancer cell lines was inhibited, and subsequent soft agar experiments showed that TTK siRNA inhibits colony size and number. These effects are associated with a disabled mitotic checkpoint, resulting in chromosome segregation errors, aneuploidy, and cell death. ${ }^{3}$ In vivo, interfering RNA meditates growth suppression of breast cancer xenografts. ${ }^{3}$ These results are supported by the fact that TTK is an essential chromosomal regulator ${ }^{4,5}$ and is overexpressed in aneuploid tumors. ${ }^{6-10}$ High TTK levels correlate with a high tumor grade ${ }^{11}$ and poor patient outcomes. ${ }^{6}$

The potential of this anticancer target is underscored by the large number of inhibitors disclosed. ${ }^{1,2,12-18}$ We pursued indazole based inhibitors which culminated in the identification of a preclinical candidate. ${ }^{2}$ The role of TTK is supported by proof-of-concept studies wherein inhibitors display cell growth inhibition in vitro and tumor growth inhibition in vivo. ${ }^{1,2,13-19}$ Moreover, several laboratories have selected TTK inhibitors for clinical trials. ${ }^{18,19}$ Our continued interest in TTK inhibitors led to a scaffold hopping exercise (Chart 1). The imidazo[1,2a]pyrazines, originally disclosed in patent applications, ${ }^{20,21}$ were the starting point for the pyrazolo $[1,5-a][1,3,5]$ triazines.
Chart 1. TTK Inhibitor Scaffold Hopping

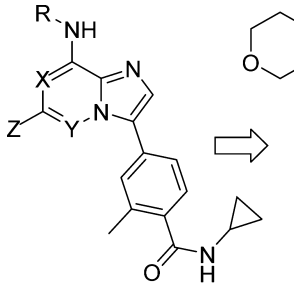

Imidazo[1,2-a]pyrazines $\mathrm{X}=\mathrm{N}, \mathrm{Y}=\mathrm{CH}$ Imidazo[1,2-b]pyridazines $\mathrm{X}=\mathrm{CH}, \mathrm{Y}=\mathrm{N}$

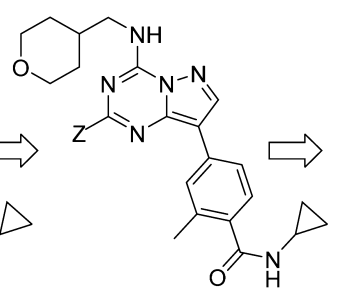

Pyrazolo[1,5-a][1,3,5] triazines

1, $Z=$ PhO- TTK IC $\mathrm{C}_{50}=1.4 \mathrm{nM}$

2, $\mathrm{Z}=$ cyclopentylNH-,

TTK IC $50=5.8 \mathrm{nM}$
R.NH

Pyrazolo[1,5-a] pyrimidines

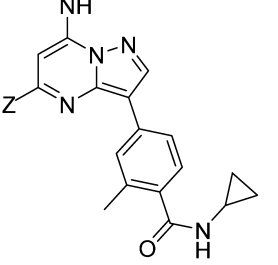

These inhibitors possess desirable attributes including biochemical potency, cell activity, and oral bioavailability (vide infra). However, rodent pharmacokinetic (PK) data indicates that certain members suffer from dissolution limiting exposure. To address this problem a further variation on the theme was

Received: December 14, 2015

Accepted: April 26, 2016

Published: May 6, 2016 
examined. Inspired by the imidazo $[1,2-b]$ pyridazines $^{20-22}$ we reasoned that a carbon for nitrogen switch at position 3 of the pyrazolo[ $1,5-a][1,3,5]$-triazines $^{23}$ would result in potent TTK inhibitors (Chart 1), i.e., the pyrazolo[1,5-a]pyrimidines described herein. A secondary benefit could accrue in that the basicity and solubility (at low $\mathrm{pH}$ ) of the latter could be increased relative to the former.

The synthesis of pyrazolo[1,5-a]pyrimidines (Scheme 1) begins with 3-bromo-5,7-dichloro-pyrazolo[1,5-a]pyrimidine 3

Scheme 1. Synthesis of Pyrazolopyrimidines ${ }^{a}$

$$
\text { (c) }
$$$$
\text { b, }
$$

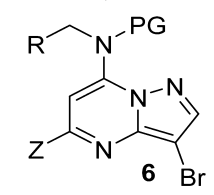

$\mathrm{PG}=\mathrm{Boc}$ or $\mathrm{PMB}$ $Z=R^{1} R^{2} N, A r O$

${ }^{a}$ Reagents and conditions: (a) DCM, DIPEA, $0{ }^{\circ} \mathrm{C}, 84-100 \%$; (b) Boc2O, TEA, DCM, 40-100\%; (c) R1R2NH, DIPEA or ArOH, K2CO3, 46-100\%; (d) N-cyclopropyl-2-methyl-4-(4,4,5,5-tetramethyl-1,3,2-dioxaborolan-2-yl)benzamide, $\mathrm{Pd}(\mathrm{dppf}) \mathrm{Cl} 2 \cdot \mathrm{CH} 2 \mathrm{Cl} 2, \mathrm{~K} 3 \mathrm{PO} 4$, H2O, THF; (e) TFA, DCE or TFA, DCM, $10-68 \%$ over 2 steps.

and proceeds by sequential displacement of halides. Intermediate 5 is obtained by nucleophilic aromatic substitution by amine 4 at the 7-position followed by protection of the nitrogen, as required. Subsequent displacement at the 5-position is affected by amines or aryloxy anions to give secondary anilines or ethers, respectively. Intermediate $\mathbf{6}$ is subjected to Suzuki-Miyaura coupling and deprotection to yield the desired products 7-24.

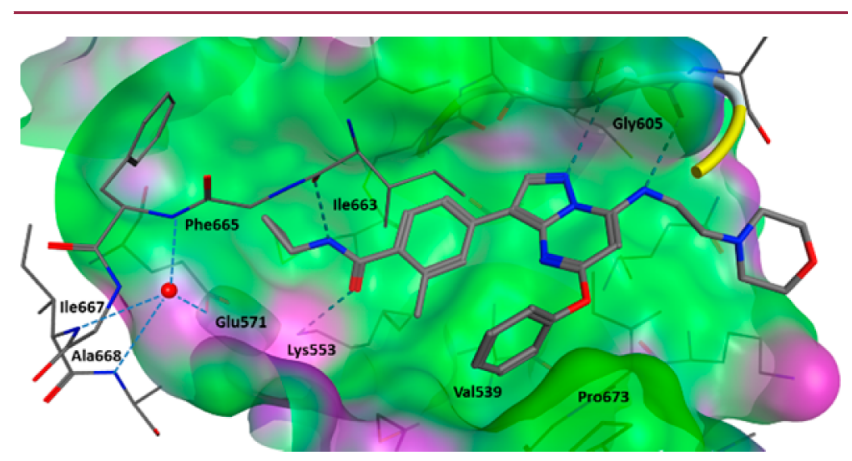

Figure 1. TTK/compound 9 cocrystallized X-ray structure (PDB: 4ZEG) with intermolecular $\mathrm{H}$-bonds indicated.

Pyrazolopyrimidines 7 and 8 were compared to their respective pyrazolotriazine congeners 1 and $\mathbf{2}$ (Table 1 ). The former pair was comparable to the latter in potency $\left(\mathrm{IC}_{50}\right)$ with much improved cell activity $\left(\mathrm{GI}_{50}\right)$ and higher oral exposure in mice. Nonetheless, it appears that the bioavailability of compound 7 is dissolution limited as we were unable to achieve plasma levels high enough to reach a maximum tolerated dose (MTD). Accordingly, a lead optimization program designed to modify the physicochemical properties was initiated. Related work ${ }^{24}$ had demonstrated the strict requirement for the $\mathrm{N}$ cyclopropyl-2-methylbenzamide at position 3 of the imidazo$[1,2-b]$ pyridazine inhibitors, ruling out further modifications here. Therefore, we modulated physicochemical properties by incorporating polar, basic, solubilizing elements into the hydrophobic and solvent exposed areas of the compounds.

To this end we applied the strategy of appending a moderately basic morpholino function at the solvent accessible region. Compounds 9 and 10 were potent TTK inhibitors, but only the latter matched the inhibition of cancer cell growth achieved by 7 . Compound 10 was orally bioavailable in mice (Table 1) and displayed a dose-dependent increase in plasma concentrations; an MTD of $6.5 \mathrm{mg} / \mathrm{kg}$ QD was established.

In an effort to better understand the TTK binding interactions of our pyrazolo[1,5-a]pyrimidine inhibitors, a cocrystallized Xray structure was obtained with compound 9 (Figure 1). A unique feature of this structure is a bound water not previously observed. ${ }^{1,2}$ The molecule is positioned to interact with NHs of the activation loop and the side chain of Glu571, but its role is uncertain in that the angles for the formation of hydrogen bonds are not ideal. The phenyloxy ring makes extensive hydrophobic interactions with Pro673 and the side chain of Val539.

The cyclopropylbenzamide carbonyl and NH coordinate with the side chain of Lys553 and Ile663 carbonyl, respectively. This indicates a highly structured activation loop and is consistent with the strict requirement for the cyclopropane amido group in this region. Two hydrogen bonds from the anilino and pyrazolo nitrogens of 9 to the hinge (Gly605) are observed. The morpholino group is in a solvent exposed region suggesting that polar substituents will be tolerated here.

Further inspection of the X-ray structure indicated that the "hydrophobic region", occupied by Z, was bounded by polar residues. This pocket corresponds to the ribose binding region of the enzyme, suggesting that polar moieties would be tolerated. Entries 11-16 in Table 1 explore the effect of introducing hydroxy alkyl amino hydrophobes. Compound $\mathbf{1 1}$ was significantly less potent than $\mathbf{8}$, but the SAR predicted that we could increase potency by incorporating additional hydrophobic bulk. This expectation was realized (compounds 12-14) and optimized by judicious selection of stereochemistry (cf. 13 and 14). Further variations on this theme yielded inhibitors 15 and 16 with equivalent enzymatic potency. However, the former suffered from reduced cell activity and oral exposure.

A third approach to modulating physicochemical properties while maintaining in vitro potency and bioavailability was pursued. Hydroxyl functions (e.g., cyclohexanol) are added to the solvent accessible region of the molecule. Simultaneously, a weak base (pyridyl) is incorporated into the aromatic hydrophobe. Both stereoisomers, $\mathbf{1 7}$ and $\mathbf{1 8}$, are potent TTK inhibitors but only the cis isomer $\mathbf{1 7}$ demonstrated desirable cell activity and oral exposure. Unfortunately $\mathbf{1 7}$ was rapidly converted to the trans isomer in vivo.

Isomerization was not seen in the cyclobutane analogues 19 and 20 but at the cost of significantly lower oral exposure. We postulated that oral bioavailability would be increased by morphing the hydroxyl cyclobutanes to tertiary alcohols as is found in compounds 21-24. In fact, these compounds are potent inhibitors of TTK; the cis congeners $\mathbf{2 3}$ and $\mathbf{2 4}$ proved to be the most orally bioavailable in mice. The latter also had the best activity against our sentinel panel of cancer cell lines.

Head to head, the solubilities of the hydroxyl containing compounds, at physiologic $\mathrm{pH}$, were not higher than their tetrahydropyranyl counterparts. However, with the incorpo- 
Table 1. In Vitro and in Vivo Data for Pyrazolo $[1,5-a][1,3,5]$ triazine and Pyrazolo[1,5-a]pyrimidine TTK Inhibitors

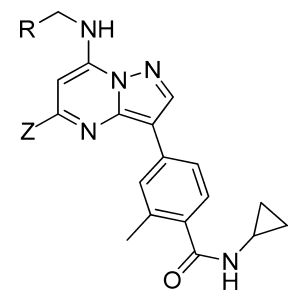

\begin{tabular}{|c|c|c|c|c|c|c|c|c|c|c|}
\hline \multirow{2}{*}{ Entry } & \multirow{2}{*}{$\mathrm{R}$} & \multirow{2}{*}{$\mathrm{Z}$} & \multirow{2}{*}{$\begin{array}{l}\text { TTK } \\
\mathrm{IC}_{50} \\
(\mathrm{nM})\end{array}$} & \multicolumn{3}{|c|}{ Cancer Cell GI ${ }_{50}(\mu \mathrm{M})$} & \multicolumn{2}{|c|}{$\begin{array}{l}\text { ACD Calc. Physicochem- } \\
\text { ical Properties }\end{array}$} & \multicolumn{2}{|c|}{$\begin{array}{c}\text { Mouse PK } \\
\text { mg/kg PO) }\end{array}$} \\
\hline & & & & $\begin{array}{l}\text { MDA-MB- } \\
468\end{array}$ & HCT 116 & $\begin{array}{c}\text { OVCAR- } \\
3\end{array}$ & $\begin{array}{c}\text { Sol. }(\mu \mathrm{g} / \mathrm{mL}) \\
\text { pH 7.4/2.0 }\end{array}$ & $\mathrm{pKa}$ & $\begin{array}{c}\mathrm{Cmax} \\
(\mu \mathrm{g} / \mathrm{mL})\end{array}$ & $\begin{array}{c}\text { AUC } \\
(\mu \mathrm{g} \cdot \mathrm{h} / \mathrm{mL})\end{array}$ \\
\hline 1 & & & 1.4 & 0.16 & 0.014 & 0.19 & $1.1 / 1.5$ & 1.6 & 0.89 & 1.5 \\
\hline 7 & & & 2.5 & 0.013 & 0.003 & 0.022 & $0.5 / 12$ & 3.4 & 0.56 & 3.1 \\
\hline 2 & & & 5.8 & 0.32 & 0.13 & 0.48 & $3.6 / 28$ & 2.7 & 0.43 & 0.53 \\
\hline 8 & & & 3.2 & 0.036 & 0.015 & 0.09 & $3.1 / 88$ & 3.2 & 2.3 & 4.0 \\
\hline 9 & & & 3.0 & 0.018 & 0.011 & 0.024 & $1.6 / 12,000$ & 6.7 & 1.0 & 2.7 \\
\hline 10 & & & 2.2 & 0.02 & 0.001 & 0.26 & $1.5 / 11,000$ & 6.7 & 1.2 & 3.6 \\
\hline 11 & & & 21 & 0.48 & 0.21 & 1.1 & $27 / 1,100$ & 3.5 & ND & ND \\
\hline 12 & & & 7.0 & 0.06 & 0.02 & 0.08 & $10 / 470$ & 3.5 & 5.5 & 20 \\
\hline 13 & & & 13 & 0.18 & 0.13 & 0.34 & $13 / 410$ & 3.3 & ND & ND \\
\hline 14 & & & 2.0 & 0.003 & 0.001 & 0.009 & $13 / 410$ & 3.3 & 2.2 & 2.4 \\
\hline 15 & & & 2.7 & 0.062 & 0.059 & 0.079 & $23 / 480$ & 3.2 & 1.3 & 1.5 \\
\hline 16 & & & 2.2 & 0.02 & 0.009 & 0.015 & $5.3 / 170$ & 3.4 & 1.7 & 3.1 \\
\hline 17 & & & 1.8 & 0.019 & 0.017 & 0.043 & $2.1 / 360$ & 3.7 & 0.75 & 3.4 \\
\hline 18 & & & 2.8 & 0.16 & 0.05 & 0.27 & $2.1 / 360$ & 3.7 & 0.19 & 0.70 \\
\hline 19 & & & 1.1 & 0.002 & 0.002 & 0.011 & $5.4 / 930$ & 3.7 & 0.12 & 0.13 \\
\hline 20 & $\mathrm{H}$ & & 2.4 & 0.035 & 0.014 & 0.068 & $5.4 / 930$ & 3.7 & 0.18 & 0.13 \\
\hline 21 & $\mathrm{HC}$ & & 5.3 & 0.13 & 0.049 & 0.21 & $3.6 / 110$ & 3.2 & ND & ND \\
\hline 22 & & & 2.4 & 0.071 & 0.04 & 0.10 & $3.3 / 560$ & 3.7 & 1.8 & 3.9 \\
\hline 23 & $\mathrm{HO}$ & & 2.6 & 0.057 & 0.014 & 0.087 & $3.6 / 110$ & 3.2 & 2.9 & 7.3 \\
\hline 24 & 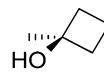 & & 1.7 & 0.002 & 0.002 & 0.004 & $3.3 / 560$ & 3.7 & 2.5 & 7.5 \\
\hline
\end{tabular}

ration of weak bases, increases in solubility were manifest at the acidic $\mathrm{pH}$ of the gastric milieu (Table 1) and allowed for the preparation of salts.
We chose four potent compounds with good oral exposure for further evaluation (Table 2). They were tested against a panel of human kinases at $1 \mu \mathrm{M}$ (Table S3). Compound 10 was the least 
Table 2. In Vitro Data, Rat and Dog PK, and Mouse Xenograft Results for Selected TTK Inhibitors

\begin{tabular}{|c|c|c|c|c|c|}
\hline \multicolumn{2}{|c|}{ study \entry } & 10 & 12 & 16 & 24 \\
\hline \multicolumn{2}{|c|}{ kinases selectivity $^{a}$} & $6 / 262$ & $1 / 262$ & $4 / 262$ & $0 / 262$ \\
\hline \multicolumn{2}{|c|}{ CYP $3 \mathrm{~A} 4 \mathrm{IC}_{50}(\mu \mathrm{M})$} & 0.78 & 3.0 & 2.0 & 0.51 \\
\hline rat $\mathrm{PK}^{b}$ & $\mathrm{Cl}(\mathrm{mL} / \mathrm{min} / \mathrm{kg})$ & 34 & 66 & 22 & 14 \\
\hline \multirow{5}{*}{$\operatorname{dog} \mathrm{PK}^{b}$} & $\begin{array}{l}\mathrm{PO} \mathrm{AUC}_{\mathrm{INF}} \\
(\mathrm{h} \cdot \mu \mathrm{g} / \mathrm{mL})\end{array}$ & 1.9 & 0.49 & 3.7 & 3.4 \\
\hline & $\mathrm{BA}(\%)$ & 77 & 38 & 94 & 53 \\
\hline & $\mathrm{Cl}(\mathrm{mL} / \mathrm{min} / \mathrm{kg})$ & 29 & 13 & 7.9 & 4.9 \\
\hline & $\begin{array}{l}\mathrm{PO} \mathrm{AUC}_{\mathrm{INF}} \\
(\mathrm{h} \cdot \mu \mathrm{g} / \mathrm{mL})\end{array}$ & 2.2 & 6.9 & 14 & 25 \\
\hline & BA (\%) & 77 & 98 & 95 & 114 \\
\hline \multicolumn{2}{|c|}{$\begin{array}{l}\text { HCT116/HT29 xenografts \% } \\
\text { TGI @ MTD }(\mathrm{mg} / \mathrm{kg})^{c}\end{array}$} & $\begin{array}{c}72 / 41 @ 6.5 \\
-6\end{array}$ & $\begin{array}{c}70 / 38 @ 15 \\
15\end{array}$ & $\begin{array}{c}72 / 53 @ 15 \\
15\end{array}$ & $\begin{array}{c}68 / 60 @ 6.5 \\
-19\end{array}$ \\
\hline \multicolumn{6}{|c|}{$\begin{array}{l}{ }^{a} \text { Number with }>50 \% \text { inhibition @ } 1 \mu \mathrm{M},[\mathrm{ATP}]=K_{\mathrm{m}} \cdot{ }^{b} \mathrm{IV} \text { dose: } 1 \\
\mathrm{mg} / \mathrm{kg} \text {. PO dose: } 5 \mathrm{mg} / \mathrm{kg} .{ }^{c} \text { Results at day } 21 .\end{array}$} \\
\hline
\end{tabular}

selective, yet only inhibited six of the 262 kinases tested (>50\% @ $1 \mu \mathrm{M})$, whereas compound 24 inhibited none. The high selectivity is attributed, in part, to the $1 \frac{1}{2}$ type nature of the binding; the $\mathrm{N}$-cyclopropyl-2-methylbenzamide group inserts deeply into the ATP binding site of TTK. As illustrated by our Xray structure, the cyclopropyl-2-methylbenzamide moiety and its binding pocket are highly complementary.

The short listed compounds were tested in a pair of xenograft models at their estimated maximum tolerated dose (MTD). Similar results were obtained for all four compounds in the HCT116 xenograft, i.e., between 68 and $72 \%$ tumor growth inhibition (TGI). A wider range of TGI was observed in the HT29 model, but all four compounds had modest responses overall. In contrast the PK parameters determined for dog spanned an order of magnitude. The very high oral exposure seen in mouse with compound $\mathbf{1 2}$ did not carry over to rat, the low AUC apparently driven by high clearance. On balance, two compounds $(16,24)$ distinguished themselves from their comparators $(10,12)$ with high oral exposure and low clearance in rat and dog.

Given its in vitro potency $\left(\mathrm{TTK} \mathrm{IC}_{50}=1.7 \mathrm{nM}\right)$, exquisite selectivity, and PK parameters, pyrazolo $[1,5-a]$ pyrimidine 24 was deemed to have the best balance of properties for subsequent preclinical evaluation. One potential issue, CYP inhibition, was examined in more detail. Compound 24, had no activity against CYPs $1 \mathrm{~A} 2$ and 2D6, inhibited $2 \mathrm{C} 9$ and $2 \mathrm{C} 19$ with $\mathrm{IC}_{50}$ s of 13 and $8 \mu \mathrm{M}$, respectively. The level of CYP $3 \mathrm{~A} 4$ activity observed was substrate dependent with $\mathrm{IC}_{50} \mathrm{~s}$ of 0.51 and $14 \mu \mathrm{M}$ for BFC and $\mathrm{DBF}$, respectively. In comparison, the TTK $K_{\mathrm{i}}$ for compound $\mathbf{2 4}$ equals $0.1 \mathrm{nM}$; however, further studies may be required to understand its potential for drug-drug interactions.

Compound $\mathbf{2 4}$ was tested against a panel of cancer cell lines from different pathologies and shown to be a potent inhibitor of cell growth (Table S1). The molecule is an intracellular inhibitor of exogenous TTK autophosphorylation with no effect on Aurora kinase A or B or Histone $\mathrm{H} 3$ phosphorylation. ${ }^{26}$ This selective inhibitor has the expected mechanism of action in cancer cells and a phenotype consistent with the inhibition of $\mathrm{TTK}^{26}$ experimental details will be disclosed in due course.

The performance of compound 24 (designated CFI-402257) in the HCT116 colorectal cancer xenograft model is illustrated in Figure S1. A dose-dependent increase in TGI versus vehicle was observed at day 21: TGI = 39\%@ @ $5.5 \mathrm{mg} / \mathrm{kg}(p=0.08)$ as compared to $68 \%$ at $6.5 \mathrm{mg} / \mathrm{kg}(p=0.01)$. There was minimal weight loss $(<10 \%)$, and no signs of overt toxicity. This level of single agent activity upon daily oral dosing is comparable to published TTK inhibitors. ${ }^{17,18}$ On the strength of the cumulative data, CFI-402257 was selected for IND enabling studies.

\section{ASSOCIATED CONTENT}

\section{S Supporting Information}

The Supporting Information is available free of charge on the ACS Publications website at DOI: 10.1021/acsmedchemlett.5b00485.

Experimental methods, extended $\mathrm{GI}_{50}$ panel (Table S1), X-ray data (Table S2), kinase screen (Table S3), and HCT116 xenograft (Figure S1) (PDF)

\section{AUTHOR INFORMATION}

\section{Corresponding Author}

*E-mail: henry.pauls@cogeco.ca. Phone: 905-337-3446.

\section{Funding}

The Canadian Institutes of Health Research (DR1-01477), Princess Margaret Cancer Foundation funded this work.

\section{Notes}

The authors declare no competing financial interest.

\section{ABBREVIATIONS}

ATP, adenosine-5'-triphosphate; AUC, area under the curve; BA, bioavailability; BFC, 7-benzyloxy-4-trifluoromethylcoumarin; Boc, tert-butoxycarbonyl; $\mathrm{Cl}$, clearance; CYP, cytochrome P450; DBF, dibenzylfluorescein; DCE, dichloroethylene; DCM, dichloromethane; DIPEA, N,N-diisopropylethylamine; dppf, 1,1'-bis(diphenylphosphino)ferrocene; $\mathrm{GI}_{50}$, half-maximal cell growth inhibitory concentration; IV, intravenous; MTD, maximum tolerated dose; Mps1, monopolar spindle 1; PDB, Protein Data Bank; PG, protecting group; PMB, p-methoxybenzyl; PO, per os (by mouth); QD, quaque die (once daily); RNAi, RNA interference; SAR, structure-activity relationship; siRNA, small interfering RNA; TGI, tumor growth inhibition; THF, tetrahydrofuran; TEA, triethylamine; TFA, trifluoroacetic acid; TTK, threonine tyrosine kinase

\section{REFERENCES}

(1) Laufer, R.; Ng, G.; Liu, Y.; Patel, N. K.; Edwards, L.; Lang, Y.; Li, S.W.; Feher, M.; Awrey, D.; Leung, G.; Beletskaya, I.; Plotnikova, O.; Mason, J.; Hodgson, R.; Wei, X.; Mao, G.; Luo, X.; Huang, P.; Green, E.; Kiarash, R.; Lin, D. C.-C.; Harris-Brandts, M.; Nadeem, V.; Mak, T. W.; Pan, J. G.; Qui, W.; Chirgadze, N. Y.; Pauls, H. W. Discovery of inhibitors of the mitotic kinase TTK based on N-(3-(3-sulfamoylphenyl)-1H-indazol-5-yl)-acetamides and carboxamides. Bioorg. Med. Chem. 2014, 22, 4968-4997.

(2) Liu, Y.; Lang, Y.; Patel, N. K.; Ng, G.; Laufer, R.; Li, S.-W.; Edwards, L.; Forrest, B.; Sampson, P. B.; Feher, M.; Ban, F.; Awrey, D. E.; Beletskya, I.; Mao, G.; Hodgson, R.; Plotnikova, O.; Qui, W.; Chirgadze, N. Y.; Mason, J. M.; Wei, X.; Lin, D. C.-C.; Che, Y.; Kiarash, R.; Madeira, B.; Fletcher, G.; Mak, T. W.; Bray, M. R.; Pauls, H. W. The Discovery of Orally Bioavailable TTK Inhibitors: 3-(4-(heterocyclyl)phenyl)-1Hindazole-5-carboxamides as Anticancer Agents. J. Med. Chem. 2015, 58, 3366-3392.

(3) Mak, T. W. Targeting the Cell Cycle in Cancer: TTK (MPS1) and PLK4 as Novel Mitotic Targets. AACR 103rd Annual Meeting, Chicago, IL, April 1-5, 2012.

(4) Kops, G. J. P. L.; Foltz, D. R.; Cleveland, D. W. Lethality to human cancer cells through massive chromosome loss by inhibition of the mitotic checkpoint. Proc. Natl. Acad. Sci. U. S. A. 2004, 101, 8699-8704.

(5) Abrieu, A.; Magnaghi-Jaulin, L.; Kahana, J. A.; Peter, M.; Castro, A.; Vigneron, S.; Lorca, T.; Cleveland, D. W.; Labbe, J. C. Mps1 is a 
kinetochore-associated kinase essential for the vertebrate mitotic checkpoint. Cell 2001, 106, 83-93.

(6) Mills, G. B.; Schmandt, R.; McGill, M.; Amendola, A.; Hill, M.; Jacobs, K.; May, C.; Rodricks, A. M.; Campbell, S.; Hogg, D. Expression of TTK, a novel human protein kinase, is associated with cell proliferation. J. Biol. Chem. 1992, 267, 16000-16006.

(7) Yuan, B.; Xu, Y.; Woo, J.-H.; Wang, Y.; Bae, Y. K.; Yoon, D.-S.; Wersto, R. P.; Tully, E.; Wilsbach, K.; Gabrielson, E. Increased expression of mitotic checkpoint genes in breast cancer cells with chromosomal instability. Clin. Cancer Res. 2006, 12, 405-410.

(8) Daniel, J.; Coulter, J.; Woo, J. H.; Wilsbach, K.; Gabrielson, E. High levels of the Mps1 checkpoint protein are protective of aneuploidy in breast cancer cells. Proc. Natl. Acad. Sci. U. S. A. 2011, 108, 5384-5389.

(9) Kilpinen, S.; Ojala, K.; Kallioniemi, O. Analysis of kinase gene expression patterns across 5681 human tissue samples reveals functional genomic taxonomy of the kinome. PLoS One 2010, 5, e15068.

(10) Landi, M. T.; Dracheva, T.; Rotunno, M.; Figueroa, J. D.; Liu, H.; Dasgupta, A.; Mann, F. E.; Fukuoka, J.; Hames, M.; Bergen, A. W.; Murphy, S. E.; Yang, P.; Pesatori, A. C.; Consonni, D.; Bertazzi, P. A.; Wacholder, S.; Shih, J. H.; Caporaso, N. E.; Jen, J. Gene expression signature of cigarette smoking and its role in lung adenocarcinoma development and survival. PLoS One 2008, 3, el651.

(11) Daniel, J.; Coulter, J.; Woo, J. H.; Wilsbach, K.; Gabrielson, E. High levels of the Mps 1 checkpoint protein are protective of aneuploidy in breast cancer cells. Proc. Natl. Acad. Sci. U. S. A. 2011, 108, 53845389.

(12) Santaguida, S.; Tighe, A.; D’Alise, A. M.; Taylor, S. S.; Musacchio, A. Dissecting the role of MPS1 in chromosome biorientation and the spindle checkpoint through the small molecule inhibitor reversine. J. Cell Biol. 2010, 190, 73-87.

(13) Kwiatkowski, N.; Jelluma, N.; Filippakopoulos, P.; Soundararajan, M.; Manak, M. S.; Kwon, M.; Choi, H. G.; Sim, T.; Deveraux, Q. L.; Rottmann, S.; Pellman, D.; Shah, J. V.; Kops, G. J.; Knapp, S.; Gray, N. S. Small-molecule kinase inhibitors provide insight into Mps1 cell cycle function. Nat. Chem. Biol. 2010, 6, 359-368.

(14) Caldarelli, M.; Angiolini, M.; Disingrini, T.; Donati, D.; Guanci, M.; Nuvoloni, S.; Posteri, H.; Quartieri, F.; Silvagni, M.; Colombo, R. Synthesis and SAR of new pyrazolo[4,3-h] quinazoline-3-carboxamide derivatives as potent and selective MPS1 kinase inhibitors. Bioorg. Med. Chem. Lett. 2011, 21, 4507-4511.

(15) Naud, S.; Westwood, I. M.; Faisal, A.; Sheldrake, P.; Bavetsias, V.; Atrash, B.; Cheung, K.-M. J.; Liu, M.; Hayes, A.; Schmitt, J.; Wood, A.; Choi, V.; Boxall, K.; Mak, G.; Gurden, M.; Valenti, M.; de Haven Brandon, A.; Henley, A.; Baker, R.; McAndrew, C.; Matijssen, B.; Burke, R.; Hoelder, S.; Eccles, S. A.; Raynaud, F. I.; Linardopoulos, S.; van Montfort, R. L.; Blagg, J. Structure-based design of orally bioavailable $1 \mathrm{H}$-pyrrolo[3,2-c]pyridine inhibitors of mitotic kinase monopolar spindle 1 (Mps1). J. Med. Chem. 2013, 56, 10045-10065.

(16) Colombo, R.; Caldarelli, M.; Mennecozzi, M.; Giorgini, M. L.; Sola, F.; Cappella, P.; Perrera, C.; Re Depaolini, S.; Rusconi, L.; Cucchi, U.; Avanzi, N.; Bertrand, J. A.; Bossi, R. T.; Pesenti, E.; Galvani, A.; Isacchi, A.; Colotta, F.; Donati, D.; Moll, J. Targeting the mitotic checkpoint for cancer therapy with NMS-P715, an inhibitor of MPS1 kinase. Cancer Res. 2010, 70, 10255-10264.

(17) Tardif, K. D.; Rogers, A.; Cassiano, J.; Roth, B. L.; Cimbora, D. M.; McKinnon, R.; Peterson, A.; Douce, T. B.; Robinson, R.; Dorweiler, I.; Davis, T.; Hess, M. A.; Ostanin, K.; Papac, D. I.; Baichwal, V.; McAlexander, I.; Willardsen, J. A.; Saunders, M.; Christophe, H.; Kumar, V. D.; Wettstein, D. A.; Carlson, R. O.; Williams, B. L. Characterization of the cellular and antitumor effects of MPI-0479605, a small-molecule inhibitor of the mitotic kinase (Mps1). Mol. Cancer Ther. 2011, 10, 2267-2275.

(18) Colombo, R.; Burbridge, M.; Rodriguez, M.; Cantero, F.; Caldarelli, M.; Giorgini, M. L.; Sola, F.; Ballinari, D.; Ciomei, M.; Bosotti, R.; Montagnoli, A.; Isacchi, A.; Donati, D.; Galvani, A. Preclinical characterization of the novel TTK kinase inhibitor S81694 for the treatment of triple-negative breast cancer. AACR 106th Annual Meeting, Philadelphia, PA, April 1-5, 2015; \#1638.
(19) Wengner, A. M.; Siemeister, G.; Koppitz, M.; Schulze, V.; Kosemund, D.; Klar, U.; Stoeckigt, D.; Neuhaus, R.; Lienau, P.; Bader, B.; Prechtl, S.; Doehr, O.; Raschke, M.; von Ahsen, O.; Elbi, C.; Bruns, I.; Michels, M.; Kreft, B.; von Nussbaum, F.; Brands, M.; Mumberg, D.; Ziegelbauer, $\mathrm{K}$. Novel Mps1 kinase inhibitors with potent anti-tumor activity. AACR 106th Annual Meeting, Philadelphia, PA April 1-5, 2015; \#3090.

(20) Kusakabe, K.-I.; Yoshida, H.; Nozu, K.; Hashizume, H.; Tadano, G.; Sato, J.; Tamura, Y.; Mitsuoka, Y. Fused imidazole derivative having TTK inhibitory action. PCT. Int. Appl. WO2011013729, 2011.

(21) Klar, U.; Koppitz, M.; Jautelat, R.; Kosemund, D.; Bohlmann, R.; Lienau, P.; Siemeister, G.; Wengner, A. M. Substituted Imidazopyridazines PCT. Int. Appl. WO2012032031, 2012.

(22) Jemaà, M.; Galluzzi, L.; Kepp, O.; Senovilla, L.; Brands, M.; Boemer, U.; Koppitz, M.; Lienau, P.; Prechtl, S.; Schulze, V.; Siemeister, G.; Wengner, A. M.; Mumberg, D.; Ziegelbauer, K.; Abrieu, A.; Castedo, M.; Vitale, I.; Kroemer, G. Characterization of novel MPS1 inhibitors with preclinical anticancer activity. Cell Death Differ. 2013, 20, 15321545 .

(23) Liu, Y.; Pauls, H. W.; Laufer, R.; Li, S.-W.; Sampson, P. B.; Feher, M.; Ng, G.; Patel, Lang, Y. Pyrazolopyrimidine compounds. PCT. Int. Appl. WO2014075168, 2014.

(24) Kusakabe, K.; Ide, N.; Daigo, Y.; Itoh, T.; Yamamoto, T.; Hashizume, H.; Nozu, K.; Yoshida, H.; Tadano, G.; Tagashira, S.; Higashino, K.; Okano, Y.; Sato, Y.; Inoue, M.; Iguchi, M.; Kanazawa, T.; Ishioka, Y.; Dohi, K.; Kido, Y.; Sakamoto, S.; Ando, S.; Maeda, M.; Higaki, M.; Baba, Y.; Nakamura, Y. Discovery of Imidazo[1,2b]pyridazine Derivatives: Selective and Orally Available Mps1 (TTK) Kinase Inhibitors Exhibiting Remarkable Antiproliferative Activity. J. Med. Chem. 2015, 58, 1760-1775.

(25) ACD/Structure Designer, version 12.01; Advanced Chemistry Development, Inc.: Toronto, ON, Canada, 2012.

(26) Mason, J. M. Campbell Family Institute for Breast Cancer Research; University Health Network, personal communication. 